\title{
AZ ÖNGYILKOSSÁG SZOCIOLÓGIÁJA
}

A történelem során minden nagy háború gazdasági és társadalmi átrendeződést vont maga után. A háborúk mellett figyelemre méltók a különböző járványok okozta nehézségek, mint a pestis vagy a kolera. Ebbe a sorba sorolhatjuk a 2020 tavaszán hazánkban is megjelenő koronavírus-járványt is, amelynek lecsengésével újabb gazdasági és társadalmi válsággal kell megküzdenünk. Szociológiai szempontból a társadalmi válság jelentőségével érdemes bővebben foglalkoznunk. A pandémia miatti elszigetelődésünk, az életünk online térbe való áthelyezése nagymértékben befolyásolja kapcsolathálózataink alakulását, az erős és gyenge kötéseink számának és minőségének változását. A gazdasági válság miatti elszegényedés, amely a munkahelyek elvesztéséből fakad, hatással bír a társadalmi rétegződés és társadalmi mobilitás alakulására is. Már látható, hogy a járványhelyzetnek lesznek nyertesei és vesztesei mind gazdasági, mind társadalmi szempontból. Legnagyobb nyertesei feltételezhetően azok lesznek, akik széles networkjüknek köszönhetően gyorsan tudják mozgósítani gyenge kötéseiket, és visszanyerni korábbi társadalmi státuszukat, újraépíteni vállalkozásaikat, kihasználni az új lehetőségeket. A járványhelyzet vesztesei ezzel szemben azok lehetnek, akik a társadalom alsó szegmenseiben helyezkednek el, és csak a hozzájuk hasonlókhoz kapcsolódnak, így nem tudnak pozitív változást kivitelezni a válságot követően, de persze mindez előfordulhat a társadalmi hierarchia felső szintjein is, csak talán ott kevésbé. A társadalmi krízis hatással van a magánéletünkre is, hiszen a Covid19 nem válogat szegények és gazdagok, híresek és közemberek között, így gyorsan szaporodik a csonka családok száma is, ami további lelki válságot, depressziót okozhat az életünk más területén már felvázolt megpróbáltatások mellett. A hosszan tartó izoláció és a társas érintkezések, baráti kapcsolatok személyes ápolása lehetőségeinek csökkenése tovább növeli a magányosságérzést. A legfontosabb változás az életünkben, hogy minden, ami eddig biztos volt, és kereteket, szabályszerüségeket adott az életünknek bizonytalanná vált. A bizonytalanság pedig növeli a deviáns viselkedések kialakulását, számuk növekedését.

Ezek fényében válik igazán aktuálissá Zonda Tamás, Bozsonyi Károly, Moksony Ferenc (szerk.): Az öngyilkosság szociológiája címü tanulmánykötete. A téma komolyságát és szomorúságát jól tükrözi a kötet fekete-kék színben való megjelenése és egy emberi arcot felfedezni sejtető (vélhetőleg fakéreg) fotó megjelentetése a könyv borítóján. Az olvasó máris valószínűsítheti, hogy egy sokszínü, de szomorú témát tartalmaz a kiadvány. A fakéreg láthatóan nem fiatal, 
utalhat arra, hogy az öngyilkosság jelenléte és egyfajta válaszlehetőségként való megjelenése bizonyos társadalmi problémákra, nem újkeletü kutatási terület. Már Émile Durkheim 1897-ben Az öngyilkosság címú munkájában elkülönített olyan „társadalmi tényeket”, amelyek befolyásolják az öngyilkosságok megjelenését és okait. A morálstatisztikai felmérések szintén már legalább kétszáz éve felhívták a figyelmet arra, hogy az öngyilkosság különböző társadalmakban és különböző társadalmi rétegekben eltérő gyakoriságú, de nagyfokúan stabilak a mutatók. Ma már széles körben elismert, hogy minden deviancia társadalmilag meghatározott, így egy adott társadalom tagjainak öngyilkosságra való hajlama az adott társadalom állapotának megnyilvánulása. Ez az állapot egy több tényező által befolyásolt komplex rendszernek mondható. A magyar társadalom a 20. század közepétől a világranglista elején helyezkedik el az öngyilkossági ráták terén. 1988-tól volt egy csökkenés, amelynek sok oka lehet, de úgy vélem a koronavírus-járvány lezajlását követően ismét emelkedő tendenciákkal kell számolnunk e téren. A kötet ezt a komplexitást célzott bemutatni, megjeleníteni. A munka tizenhárom tanulmányt tartalmaz, olyan, a területen kiemelkedö kutatók munkáival és friss kutatási eredményeivel, mint Bálint Lajos, Moksony Ferenc, akik több tanulmányukkal is bekerültek a kötetbe. A dolgozatok nagy része az önkezü halál klasszikus társadalmi mintázataira koncentrál, különböző módszerekkel árnyalva az egyes összefüggéseket, további empirikus bizonyítékokkal gazdagítva az eddigi adatsorokat, az akár vallási, akár kulturális státusz menti vagy urbanizációs tendenciák hatására kiváltódott öngyilkosságok megjelenéseit. A kötetben Hegedűs Rita által olvashatunk az öngyilkossággal kapcsolatos attitűdökröl, vagy Kmetty Zoltán és Palusek Erik révén a jeles napok, ünnepek és öngyilkosságok viszonyairól is. Egyedi munkának mutatkozik Bódán Zsolt néprajztudomány területéról bevont eszmefuttatása és esettanulmány ismertetése a gyimesi csángók öngyilkossághoz való attitüdjéről. A kiadványban Moksony Ferenc és Zonda Tamás tollából egyaránt olvashatunk szaktanulmányt az öngyilkossággal kapcsolatos társadalomkutatások módszertani dilemmáiról, kérdéseiről is. A témakör vizsgálatát megkoronázza két nagyon érdekes tanulmány a kötet végén. Az egyikben az öngyilkosságok meteorológiai meghatározottságáról olvashatunk, a másikban annak cáfolatáról, hogy az antidepresszánsok szedése összefüggésben van az öngyilkossági mutatók csökkenésével. Ez a gondolat a pszichológiai és pszichiátriai vizsgálatokat is segíteni kívánja a témában.

A Covid19-járvány szempontjából a francia származású szociológus Durkheim tipológiájához érdemes visszanyúlnunk. Ahogy ismertetésem elején említettem általános bizonytalanság uralkodik jelenleg a hazai társadalmunkban. Durkheim szerint a társadalmi rend egyensúlyának megbillenése és az új rendszer bizonytalanságának állapota, amit jelenleg tapasztalunk, úgynevezett anómiás öngyilkosságokat válthat ki. A durkheimi négyes tipológiából ezzel biztos, hogy számolnunk kell az elkövetkezö években, ahogy az egoista típusú öngyilkosságok 
növekvő számával is. Ez utóbbit előidézheti a válások növekvő száma, a közvetlen családtagok elvesztése a fertőzés miatt, vagy pusztán a társadalmi hierarchia átrendeződéséből adódó nehézségek egyaránt. A kezdeti kutatások arra hívták fel a figyelmet, ahogy Moksony Ferenc is írja a társadalmi-gazdasági fejlődés és öngyilkosság kapcsolatait taglaló tanulmányában, hogy a deviáns viselkedések a fejlődés „árának” voltak tekinthetők, amit az újabb vizsgálatok kiegészítettek azzal, hogy a fejlődésből kimaradó társadalmi csoportok vagy lakóhelyi térségek kimondottan veszélyeztetettek az önkezü halál elkövetésében. Ennek tanulságaként a deprivált helyzetbe kerülő honfitársainkra kimondott figyelmet kell fordítanunk, mint felelós állampolgárok nem várhatjuk minden társadalmi probléma megoldását a kormányzattól. Figyelnünk kell egymásra és magunkra egyaránt a kilábalás időszakában, hogy a kötetben megjelenő statisztikai adatok ne mutassanak további emelkedést.

A világjárvány okozta társadalmi változások ma már nemcsak az elképzelt világokat bemutató disztópikus szépirodalmi munkákban jelennek meg, hanem az elmúlt időszakban valósággá vált néhány elemük. Szemmel láthatóan átalakultak emberi kapcsolataink, a kapcsolatok fenntartásának, ápolásának formái, a kapcsolati tőkénk nagysága, minősége, de értékrendszerünk is. A változás még nem fejeződött be, még sok kihívás áll hazánk és az egész világ előtt, hogy újra stabilizálódjon a gazdasági rendszer és a társadalom is. A tanulmánykötet összességében egyértelműen motiváló hatással bír, és további kutatásokhoz adhat ihletet mind a szociológia, pszichológia, kulturális antropológia, de a néprajztudomány területein is a szakemberek számára. A tudományos közegeken kívül, hasznos lehet azok számára is, akik általában érdeklődnek a deviáns viselkedések iránt, vagy céltudatosan az öngyilkosság miértjeire keresik a lehetséges magyarázatot, vagy a jelenség hátterébe kívánnak betekintést nyerni.

(Zonda Tamás - Bozsonyi Károly - Moksony Ferenc szerkesztők: Az öngyilkosság szociológiája. Budapest: L'Harmattan Kiadó, 2019, 390 o.)

Janó Evelin

PhD-hallgató

Eötvös Loránd Tudományegyetem Társadalomtudományi Kar Szociológia Doktori Iskola 